\title{
Combined effect of heat treatment and ionic strength on the functionality of whey proteins
}

\author{
R. Hussain, ${ }^{\star}$ C. Gaiani, ${ }^{\star 1}$ C. Jeandel, ${ }^{\star}$ J. Ghanbaja,† and J. Scher ${ }^{\star}$ \\ *Université de Lorraine, Laboratoire d'Ingénierie des Biomolécules (LIBio), 2 avenue de la Forêt de Haye, B.P. 172, \\ 54505 Vandœuvre-lès-Nancy, France \\ †Université de Lorraine, Faculté des Sciences, Service commun de Microscopie Electronique par Transmission, BP 239, \\ Boulevard des Aiguillettes F-54506 Vandœuvre-lès-Nancy, France
}

\begin{abstract}
A $5 \%(\mathrm{wt} / \mathrm{vol})$ whey protein isolate (WPI) dispersion ( $\mathrm{pH}$ 6.5) with different concentrations of $\mathrm{NaCl}$ was submitted to dynamic heat treatment. Protein dispersions were characterized as to their rheological properties, particle sizes, morphology, denaturation temperatures, and protein surface hydrophobicity. At low ionic strength $(<200 \mathrm{mmol} / \mathrm{kg})$, gel elastic modulus increased and strongest gel stiffness was achieved. High salt concentrations lead to a weaker gel, whereas no gels at all were formed without salt. The gelation temperature was also influenced by ionic strength and an increase in denaturation temperature and thermal stability was also observed by using differential scanning calorimetry. Additionally, heat-induced changes in secondary structures upon salt augmentation were followed by Fourier transform infrared spectroscopy. Secondary structural elements estimations obtained from amide I assignments were correlated with those from amide III assignments. Upon salt increase, no differences in secondary structure were observed without heating, whereas upon heating and without salt increase, the Fourier transform infrared spectroscopy data revealed an increase in intermolecular $\beta$-sheets at the cost of $\beta$-turns and random coils, with no change in $\alpha$-helical structures. However, $\mathrm{NaCl}$ addition along with dynamic heat treatment of WPI dispersion showed a stabilizing effect on the secondary structural elements of both amide I and amide III bands. Whey protein isolate dispersions in water were also characterized by transmission electron microscopy by a spherical shape with 2 populations (6 and $70 \mathrm{~nm}$ ). Salt increase alone resulted in the formation of denser aggregates, whereas a transition from spherical/compact protein aggregates to linear ones was observed due to combined salt/heat
\end{abstract}

Received February 7, 2012.

Accepted July 21, 2012.

${ }^{1}$ Corresponding author: claire.gaiani@ensaia.inpl-nancy.fr effect. The important size of these edifices was confirmed by microscopy and light-scattering techniques. Moreover, protein surface hydrophobicity related to the number of hydrophobic sites available decreased significantly. Finally, experimental results demonstrated the strong interaction between ionic strength and dynamic thermal treatment on protein functional properties and their careful adjustment could enable the food industry to effectively use WPI as a gelling agent.

Key words: whey protein, ionic strength, conformational change, temperature

\section{INTRODUCTION}

Whey proteins are among the most used and versatile sources of functional and nutritional food proteins. These represent a high nutritional profile with specific physiological properties and are widely used in the food industry (Madureira et al., 2010). Most probable food applications are in bakery products, processed meats, pasta, ice cream, confectionary, infant foods, spreads, dips, and beverages (Mulvihill and Ennis, 2003). Whey proteins are composed of 2 major fractions, $\beta-\mathrm{LG}$ and $\alpha-L A$, representing, respectively, 54 and $21 \%$. $\beta$-Lactoglobulin and $\alpha$-LA are globular proteins consisting of 162 and 123 AA residues, respectively. With the advent of industrial filtration and separation methods, recovery and fractionation of whey proteins in their native form had become possible. Consequently, a wide variety of whey protein isolates (WPI), fractions, and hydrolysates are currently available (Nicorescu et al., 2008; Madureira et al., 2010).

Sodium chloride is an alimentary salt widely used in the dairy industry, as it is a major determinant of water activity. It is well known that microenvironments such as $\mathrm{pH}$ or salt, or both, can significantly alter the behavior and overall performance of proteins. In addition, whey proteins have an important cation-binding capacity (Hussain et al., 2011b). Addition of $\mathrm{NaCl}$ to whey proteins was found to generally enhance the formation of denser aggregates with turbidity, molecular 
size increase, and a protein solubility decrease (Vardhanabhuti and Foegeding, 2008; Hussain et al., 2011b). Sodium chloride could also affect the hydration process of proteins by electrostatic shielding and ion-specific hydrophobic interactions (Boye et al., 1996; Hussain et al., 2011b). Whey proteins in aqueous solution denature when heated, leading to an irreversible aggregation process and eventually a gel is formed above a critical protein concentration (Schmitt et al., 2007).

The aggregation process and gel structure are linked to various parameters $(\mathrm{pH}$, protein concentration, temperature, and amount and type of salt, among others; Ikeda et al., 1999; Schmitt et al., 2011). Nevertheless, the mechanism of salt/heat-induced gelation of commercial whey proteins has been the subject of many studies in recent years. The denaturation/aggregation behavior of whey proteins were examined as a function of heating temperature in the presence of different salt media. In recent studies conducted specifically on whey proteins, an effort was made to understand the phenomenon and kinetics of salt/heat-induced gelation and its interpretation regarding protein functionality (Unterhaslberger et al., 2006; Schmitt et al., 2007; Nicorescu et al., 2008; Schmitt et al., 2011). Notwithstanding, the complete mechanism of salt/heat-induced gelation of whey proteins is still far from being understood. To better understand this process regarding rheological, morphological, and structural alterations in WPI, techniques able to probe their molecular structure and interactions are required. In earlier investigations, limited techniques have been used to determine the combined effect of heat and salt on the functionality of whey proteins. For example, rheological techniques have been used to determine gel properties such as gelation temperature and the storage $\left(\mathbf{G}^{\prime}\right)$ or loss modulus $\left(\mathrm{G}^{\prime \prime}\right)$ of salt/heat-induced WPI gels (Lorenzen and Schrader, 2006). Respectively, some researchers used various microscopic, calorimetric, and light-scattering techniques to characterize denaturation/aggregation behavior of whey proteins in an aqueous or salt environment, or both (Schmitt et al., 2007; Nicorescu et al., 2008).

Fluorescence titration using hydrophobicity probes such as 1-anilino-8-naphthalenesulfonate (ANS) has been proposed with success for the evaluation of whey protein surface hydrophobicity in variable media (Van Audenhaege et al., 2010; Schmitt et al., 2011). Globular proteins present compact and ordered conformations because of the presence of disulfide bridges, which give them a well-defined secondary and tertiary structure. The circular dichroism spectrum of proteins can reveal important characteristics of their secondary structure (Qi and Onwulata, 2011) but this technique presents some restrictions. Nonperiodic $\beta$-turn structures cannot be distinguished by this methodology (Kavanagh et al., 2000). Fourier transform infrared (FTIR) spectroscopy is becoming an increasingly important method to study protein secondary structure, mostly by the analysis of the amide I region. With the use of FTIR, various elements of the secondary structures of whey proteins for amide I (Byler and Susi, 1986) and amide III (Cai and Singh, 1999, 2004) have already been determined.

In this paper, we present an investigation of the behavior leading up to heat/salt-induced gelation of WPI $(5 \% \mathrm{wt} / \mathrm{vol})$ as a function of variable $\mathrm{NaCl}$ concentrations $(0$ to $3 \%)$ and temperatures $\left(30\right.$ to $\left.90^{\circ} \mathrm{C}\right)$. The emphasis of this study is to relate the rheological and morphological properties of salt/heat-induced gels of WPI to the particle size, hydrophobicity, and interactions of the protein molecules in the gel network. For this purpose, a multilevel characterization was carried out by using FTIR spectroscopy, transmission electron microscopy (TEM), light-scattering techniques [dynamic light scattering (DLS) and static light scattering (SLS)], differential scanning calorimetry (DSC), and several other complementary techniques.

\section{MATERIALS AND METHODS}

\section{Materials}

Whey protein isolate powder was provided by Lactalis (Laval, France). The composition of the powder was (\% by weight, wt $/ \mathrm{wt}$ ) $89.9 \%$ proteins (Kjeldahl $\mathrm{N} \times$ $6.38), 0.5 \%$ fat, $1.0 \%$ lactose, $3.1 \%$ ash, and $5.5 \%$ moisture. Sodium chloride was furnished by VWR (Prolabo, Leuven, Belgium). Sodium azide (Merck KGaA, Darmstadt, Germany) was added as antimicrobial agent in each rehydration media $(0.2 \mathrm{~g} / \mathrm{L})$. The $\mathrm{pH}$ (mean \pm SD) of all systems studied was stable around $6.5 \pm 2$.

Analyses were performed on totally rehydrated WPI powders at $5 \%$ wt (protein basis) in $\mathrm{NaCl}$ media at variable salt concentrations ranging between 0 and $3 \%$ salt. To obtain total rehydration of the powder, the dispersion was left under stirring overnight (12 h; Gaiani et al., 2007) and referred to throughout this paper as WPI dispersion. To investigate the effect of heat treatment on WPI dispersions and particularly on the formation of heat-induced aggregates by TEM, DLS, and protein surface hydrophobicity (PSH), supernatants were collected (i.e., the soluble fraction). Whey protein isolate dispersions were transferred into $22-\mathrm{mL}$ glass vials (with a screw top and solid cap) and heated in a water bath with a thermometer without stirring up to $90^{\circ} \mathrm{C}$. Afterwards, the samples were immediately cooled in ice water to $4^{\circ} \mathrm{C}$ and measurements for the 
characterization of dispersion properties were immediately carried out.

\section{Particle Size and Structure Determination}

Particle Size. Particle sizes of WPI dispersions were measured at 30 and $90^{\circ} \mathrm{C}$ using 2 different pieces of light-scattering equipment. For the smallest sizes (between 0.5 and $400 \mathrm{~nm}$ ), a Nanosizer ZS particle size analyzer (HPPS 5001; Malvern Instruments Ltd., Malvern, UK) was used. Intensity autocorrelation functions were analyzed by a CONTIN algorithm to determine the distribution of translational z-averaged diffusion coefficient of particles $\left(D_{\mathrm{T}}\right)$. From the algorithm, the determination of the hydrodynamic diameter $\left(\mathbf{D}_{\mathbf{h}}\right)$ was deduced from the hydrodynamic radius $\left(\mathbf{R}_{\mathbf{h}}\right), \mathrm{D}_{\mathrm{h}}=2 \times$ $\mathrm{R}_{\mathrm{h}}$. For the largest sizes (between 0.1 and 1,000 $\mu \mathrm{m}$ ), a laser diffraction instrument (Mastersizer S; Malvern Instruments Ltd.) with a 5 -mW He-Ne laser operating at a wavelength of $632.8 \mathrm{~nm}$ and 300RF lens was used. Almost $50 \mathrm{~mL}$ of WPI dispersion was diluted in $200 \mathrm{~mL}$ to obtain a correct obscuration (around 15).

Transmission Electron Microscopy. Microstructures of WPI dispersions under $\mathrm{NaCl}$ environments were determined at various temperatures $\left(30\right.$ to $\left.90^{\circ} \mathrm{C}\right)$ by TEM (CM20 Philips; $25,000 \times$ magnification; Koninklijke Philips Electronics NV, Amsterdam, the Netherlands) using a negative staining method. One drop of dispersion was deposited onto a carbon-coated copper grid (200 mesh, 3-mm diameter). The excess of product was removed after $30 \mathrm{~s}$ using filter paper. Subsequently, 1 drop of uranyl acetate $(2 \%)$ was placed on the grid for 2 min. After drying the grid at room temperature for 5 min, micrographs were made using TEM operating at $200 \mathrm{kV}$. Images were recorded using an Olympus TEM CCD camera (Olympus Soft Imaging Solutions GmbH, Münster, Germany). Image contrast was improved by contrast stretching with Adobe Photoshop Elements 2.0 software (Adobe Systems Inc., San Jose, CA).

\section{Rheological Measurements}

Rheological measurements were performed with a Kinexus rotational rheometer (KNX 2100 UK; Malvern Instruments Ltd.). The rheometer was equipped with a temperature control unit (Peltier effect), allowing the obtaining of very precise temperature ramp. The timetemperature course of gel formation was characterized by small-deformation oscillatory measurements $(0.01 \%$ strain; $1.0 \mathrm{~Hz}$ ) of the $\mathrm{G}^{\prime}$ using parallel plate geometry $\mathrm{CP} 2 / 50$ (cone and plate geometry with a $50-\mathrm{mm}$ diameter and a cone angle of $2^{\circ}$ ). The gelation temperature was defined as the temperature at which the $\mathrm{G}^{\prime}$ starts to increase. Various salt dispersions (from 0 to $3 \%$ ) were heated from 30 to $90^{\circ} \mathrm{C}$ at a rate of $1^{\circ} \mathrm{C} / \mathrm{min}$. Paraffin oil was applied to the sample exposed surface to prevent water evaporation (Michalski et al., 2002).

\section{Thermal Denaturation}

Thermograms of WPI dispersions in presence or absence of salt were studied by DSC using a micro DSC III (Setaram Instrumentation, Caluire, France). Whey protein isolate dispersions $(850 \mathrm{mg})$ were hermetically sealed in a pan (Hastelloy C276; volume $=1 \mathrm{~cm}^{3}$ ), and the reference pan was filled with water (Milli-Q water; Millipore Corp., Billerica, MA) or appropriate salt solutions, or both. After equilibration for $10 \mathrm{~min}$ at $10^{\circ} \mathrm{C}$, the temperature was raised to $90^{\circ} \mathrm{C}$ at a heating rate of $1.2^{\circ} \mathrm{C} / \mathrm{min}$ and then cooled to $30^{\circ} \mathrm{C}$ at $2^{\circ} \mathrm{C} / \mathrm{min}$. The total calorimetric apparent enthalpy change $(\Delta \mathrm{H})$ was obtained by integrating the area of the thermogram using a straight line between the onset and the final temperature of the thermal transition. Also, the denaturation temperatures $\left(\mathrm{T}_{\mathrm{D}}\right)$ were determined from the integration of the calorimetric thermograms.

\section{Surface Hydrophobicity Index Determination}

For PSH determination, diluted WPI dispersions $(0.05 \%)$ in quartz cells were placed in a spectrofluorometer (F2500; Hitachi Ltd., Tokyo, Japan) and aliquots of ANS were successively added (from 0 to 50 $\mu \mathrm{mol} / \mathrm{L}$; Schmitt et al., 2009). Titration with ANS was monitored at an excitation wavelength $\left(\lambda_{\text {ex }}\right)$ of $390 \mathrm{~nm}$ and emission wavelength $\left(\lambda_{\mathrm{em}}\right)$ of $480 \mathrm{~nm}$. The relative fluorescence intensity reading was adjusted to 1 when $50 \mu \mathrm{L}$ of ANS solution was added to PBS (at $0.10 \mathrm{mM}$ and $\mathrm{pH}$ 7). Analysis of binding data was performed to obtain the maximum fluorescence attainable at saturating ANS concentration $\left(\mathbf{F}_{\max }\right)$. The $\mathrm{F}_{\max }$ is a function of the number of hydrophobic sites accessible to the spectroscopic marker. The ANS concentration required to obtain half the value of $\mathrm{F}_{\max }$ is considered to be the apparent dissociation constant of the fluorescent ANS-protein complex $\left(\mathbf{K}_{\mathrm{d}}\right)$. The ratio $\mathrm{F}_{\max } / \mathrm{K}_{\mathrm{d}}$ or PSH represents a cumulative index of surface hydrophobicity of protein, taking into account both the number and affinity of hydrophobic sites.

\section{Protein Secondary Structure}

Equipment. Protein secondary structures were followed by FTIR spectroscopy. Scans were obtained with a Tensor 27 mid-FTIR Bruker spectrometer (Bruker AXS GmbH, Karlsruhe, Germany) equipped with an 
attenuated total reflectance (ATR) cell and a mercury cadmium telluride (MCT) detector cooled with liquid $\mathrm{N}_{2}$. The scanning rate was $20 \mathrm{kHz}$ and 126 scans were used for reference and samples between 4,000 and 850 $\mathrm{cm}^{-1}$. The nominal instrument resolution was $2 \mathrm{~cm}^{-1}$. A rheostat (Haake DC 30; Meyer-Haake GmbH Medical Innovations, Ober-Mörlen, Germany) was connected with the ATR cell to regulate the temperature between 30 and $90^{\circ} \mathrm{C}$ at the rate of $2^{\circ} \mathrm{C}$ rise per measure (OPRO Protein Dynamics; Bruker AXS GmbH). First, references were recorded for water or $\mathrm{NaCl}$ solutions according to their concentrations. Then, $20 \mu \mathrm{L}$ of WPI dispersion was put on the ZnSe crystal of the optical cell. The same temperature ramp was performed for references and samples. Three to 5 separate experiments were done for each salt concentration.

Data Treatment. All treatments were carried out using OPUS software (Bruker AXS GmbH). Raw absorbance spectra were smoothed using a 9-point Savitzky-Golay smoothing function. Spectra were cut between 1,720 and $1,580 \mathrm{~cm}^{-1}$ or between 1,190 and $1,390 \mathrm{~cm}^{-1}$ for analysis of amide I and amide III bands, respectively. Elastic baseline correction using 200 points was then applied to spectra. After that, spectra were centered and normalized using OPUS software. Secondderivative spectra were calculated on centered and normalized data to identify individual peak positions. Finally, the treated spectra were deconvoluted by a nonlinear regression curve-fitting program of Gaussian peaks to the original spectra. Integrated areas of each peak were calculated and related to secondary structural features (Byler and Susi, 1986; Cai and Singh, 1999; Hussain et al., 2011a).

\section{Statistical Analyses}

Statistical analysis was carried out by using the software KyPlot version 2.0 (http://www.kyenslab.com/ en/products/kyplot.html). For comparisons between dispersion in water and other $\mathrm{NaCl}$ concentration, parametric multiple tests were performed (Dunnett test with whey dispersions in water as control). The level of statistical significance was $P<0.05$.

\section{RESULTS}

\section{Particle Sizes of WPI Dispersions}

Particle sizes were determined by DLS or SLS, or both, to measure the $\mathrm{D}_{\mathrm{h}}$ or particle diameters, or both (Table 1). The choice of the technique (DLS or SLS) depended mainly on the particle size range. Aggregates larger than $500 \mathrm{~nm}$ could not be correctly measured by
DLS. Conversely, aggregates under $200 \mathrm{~nm}$ were not correctly evaluated by SLS. The distributions obtained in water at $30^{\circ} \mathrm{C}$ were bimodal. Indeed, 2 populations were systematically observed. The first peak at $6 \mathrm{~nm}$ was significantly less represented than the second peak at $69 \mathrm{~nm}$. Similar size was also observed by the analysis of a significant number of particles from TEM images $(\approx 70 \mathrm{~nm})$. For $0.50 \%$ salt $(86 \mathrm{mmol} / \mathrm{kg})$, similar $\mathrm{D}_{\mathrm{h}}$ were measured. Nevertheless, the second peak (72 nm) was more important and represented more than $90 \%$ of the total particles. Concurrently, the major second peak exhibited a $D_{\mathrm{h}}$ of 160 and $316 \mathrm{~nm}$ for $1 \%$ (172 mmol/ $\mathrm{kg})$ and $1.5 \%$ salt $(258 \mathrm{mmol} / \mathrm{kg})$, respectively. As a consequence, the DLS technique was still possible up to $1.5 \%$ salt $(258 \mathrm{mmol} / \mathrm{kg})$ but not for higher concentrations, where SLS was more appropriate. For higher salt concentrations, similar particle sizes presenting 2 populations were found by SLS. The first population was related to small aggregates $(420 \mathrm{~nm})$ already noticed by DLS for lower salt concentrations. The second and most important population was related to large aggregates (around $35 \mu \mathrm{m}$ ) impossible to detect by DLS. These statements are reinforced with the images of TEM.

Particle sizes of heated WPI dispersions were also measured. Distributions were systematically monomodal whatever the ionic environment. In water, a $D_{h}$ of $263 \mathrm{~nm}$ was observed that corresponded fairly well with TEM images. With salt addition, a significant shift toward smaller sizes (from 246 to $85 \mathrm{~nm}$ ) was observed, showing a decreasing trend of $\mathrm{D}_{\mathrm{h}}$ after heating.

\section{Morphological Characterization of WPI Dispersions}

The specific and combined effect of salt and heat on the morphology of WPI dispersions is highlighted in the TEM images presented in Figure 1. Without salt and at $30^{\circ} \mathrm{C}$, well-separated roughly spherical nanoparticle structures presenting particle sizes below $70 \mathrm{~nm}$ were observed (Figure 1A-0\%). At relatively low salt concentration $(86 \mathrm{mmol} / \mathrm{kg})$, small clumpy aggregates were noticed in addition to the well-separated spherical nanoparticles (Figure 1A-0.5\%). When the NaCl concentration was increased up to $258 \mathrm{mmol} / \mathrm{kg}$, the aggregates were clearer, denser, and larger (Figure 1A-1\% and 1A-1.5\%). Finally, particle aggregation clearly appeared in higher ionic environments (344 to $517 \mathrm{mmol} /$ $\mathrm{kg})$. A change in the structure of protein aggregates was observed, the aggregates being bigger and denser (Figure $1 \mathrm{~A}-2 \%$ to $1 \mathrm{~A}-3 \%$ ).

Figure $1 \mathrm{~B}$ shows the result of heat $\left(90^{\circ} \mathrm{C}\right)$ on WPI dispersions. Without adding salt, compact/spherical aggregates took the form of white masses due to the 
Table 1. Particle sizes (nm) obtained by static light scattering (SLS), dynamic light scattering (DLS), and from transmission electron microscopy (TEM) image analysis (mean of 3 independent measures)

\begin{tabular}{|c|c|c|c|c|c|c|c|}
\hline $\begin{array}{l}\mathrm{NaCl} \\
(\%)\end{array}$ & \multicolumn{5}{|c|}{ At $30^{\circ} \mathrm{C}$} & & \\
\hline 0 & $5.8 \pm 0.2$ & $69.4 \pm 5.9$ & $-^{2}$ & - & $\approx 70$ & $263 \pm 1.5$ & $\approx 255$ \\
\hline 0.50 & $11.3 \pm 0.8^{*}$ & $72.0 \pm 2.6^{\mathrm{NS}}$ & - & - & $\approx 85^{\mathrm{NS}}$ & $246 \pm 1.9^{\mathrm{NS}}$ & $\approx 228^{\mathrm{NS}}$ \\
\hline 2.00 & - & - & $420 \pm 6^{* * *}$ & $35,560 \pm 13^{* * *}$ & $\approx 660 * * *$ & $101 \pm 1.3^{* *}$ & $\approx 100^{* *}$ \\
\hline 2.50 & - & - & $420 \pm 9^{* * *}$ & $35,560 \pm 7^{* * *}$ & $>1,000^{* * *}$ & $88 \pm 6.2^{* *}$ & $\approx 100^{* *}$ \\
\hline 3.00 & - & - & $420 \pm 5^{* * *}$ & $35,560 \pm 5^{* * *}$ & $>1,000^{* * *}$ & $85 \pm 8.8^{* *}$ & $\approx 100^{* *}$ \\
\hline
\end{tabular}

${ }^{1}$ Mean of at least 10 particles observed in 3 different TEM images.

${ }^{2}$ Dashes: not determined due to equipment limitation.

${ }^{* * *} P<0.001 ;{ }^{* *} P<0.01 ;{ }^{*} P<0.05 ;{ }^{\mathrm{NS}} P>0.05$ [comparisons between whey dispersion in water (control) and other concentration].

negative staining method used (Figure 1B-0\%). The images also depict regions of excess stain, originating from the negative staining preparation method. These structures present particle sizes around $260 \mathrm{~nm}$. With addition of $\mathrm{NaCl}$ at relatively low concentration (86 $\mathrm{mmol} / \mathrm{kg}$ ), rather thinner and denser aggregates were

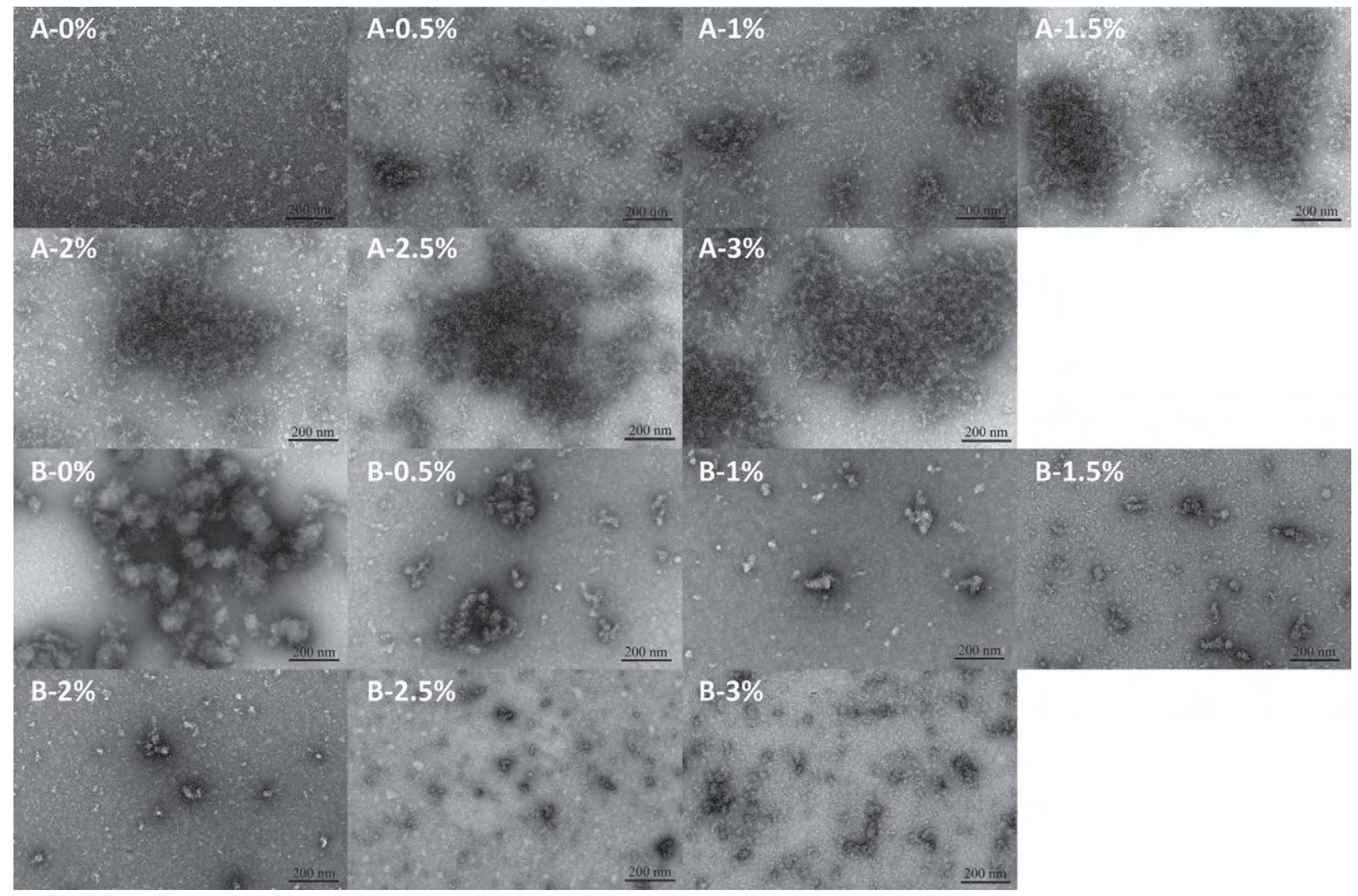

Figure 1. Transmission electron micrographs of whey protein isolate (WPI) dispersions after being heated at $30^{\circ} \mathrm{C}(\mathrm{A})$ and $90^{\circ} \mathrm{C}(\mathrm{B})$ and in variable $\mathrm{NaCl}$ environments $(0,0.5,1,1.5,2,2.5$, and $3 \%$ salt). Imaging was performed at 24,000× magnification (scale bar $=200 \mathrm{~nm})$. Each image is representative of at least 6 images observed. 
observed (Figure 1B-0.5\%). Upon increasing the salt concentration to $1.50 \%(258 \mathrm{mmol} / \mathrm{kg})$, these spherical aggregates tended to be smaller and well dispersed (Figure 1B-1\% and 1B-1.5\%). Finally, at higher salt environments of 2 to $3 \%$ (344 to $517 \mathrm{mmol} / \mathrm{kg}$ ), particles were characterized by a length less than $100 \mathrm{~nm}$, less numerous, and more irregular in form (Figure 1A-2\% to $1 \mathrm{~A}-3 \%)$.

\section{Rheological and Thermal Properties of WPI Dispersions}

In Figure 2, WPI dispersions under variable $\mathrm{NaCl}$ ranges are plotted against the elastic modulus as a function of a heat ramp $\left(30-90^{\circ} \mathrm{C}\right)$. A change in the viscoelastic properties of the dispersions was observed when subjected to thermal treatment. Without the addition of salt, the WPI dispersions showed nongelling behavior, presenting low values of $\mathrm{G}^{\prime}$ throughout heating and holding a translucent appearance. In the presence of $\mathrm{NaCl}$, the values of $\mathrm{G}^{\prime}$ increased strongly between 75 and $80^{\circ} \mathrm{C}$, showing a viscoelastic behavior and a plateau curve convincingly indicating an inflection point as temperature approached $88^{\circ} \mathrm{C}$, demonstrating the formation of a continuous protein network. Furthermore, with addition of $0.50 \% \mathrm{NaCl}$, a sharp increase in the modulus was observed at $76^{\circ} \mathrm{C}$, whereas this behavior was noted at $80^{\circ} \mathrm{C}$ for $3 \% \mathrm{NaCl}$, showing a significant increase in the gelling temperature.

The effect of $\mathrm{NaCl}$ addition on the thermal properties of WPI dispersions was examined by $\mu$ DSC (Figure 3 ). In addition, their corresponding values of denaturation temperature are shown in Figure 4. The endothermic transition peaks indicated that structural changes were associated with temperature. The denaturation temperature of WPI dispersion without salt was $76.4^{\circ} \mathrm{C}$, which shifted toward a higher temperature of $78.4^{\circ} \mathrm{C}$ at $0.50 \%$ salt. Increasing the $\mathrm{NaCl}$ concentration to $3 \%$ increased the denaturation temperature up to $80.2^{\circ} \mathrm{C}$.

\section{Protein Hydrophobicity}

Analysis of the emission spectra (data not shown) of ANS-WPI dispersions in variable $\mathrm{NaCl}$ solutions with or without heating revealed a representative set of titration curves. Investigation of binding data allows the determination of values of $\mathrm{F}_{\max }$ at saturating ANS concentration. The $\mathrm{F}_{\max }$ is determined by the asymptotic value of the titration curve. The $\mathrm{K}_{\mathrm{d}}$ of the fluorescent ANS-protein complex is determined as the ANS concentration required to obtain half the value of $\mathrm{F}_{\max }$. From these 2 values, the PSH was calculated and indicated the binding average of the fluorescent marker to available hydrophobic sites of protein (Schmitt et al.,

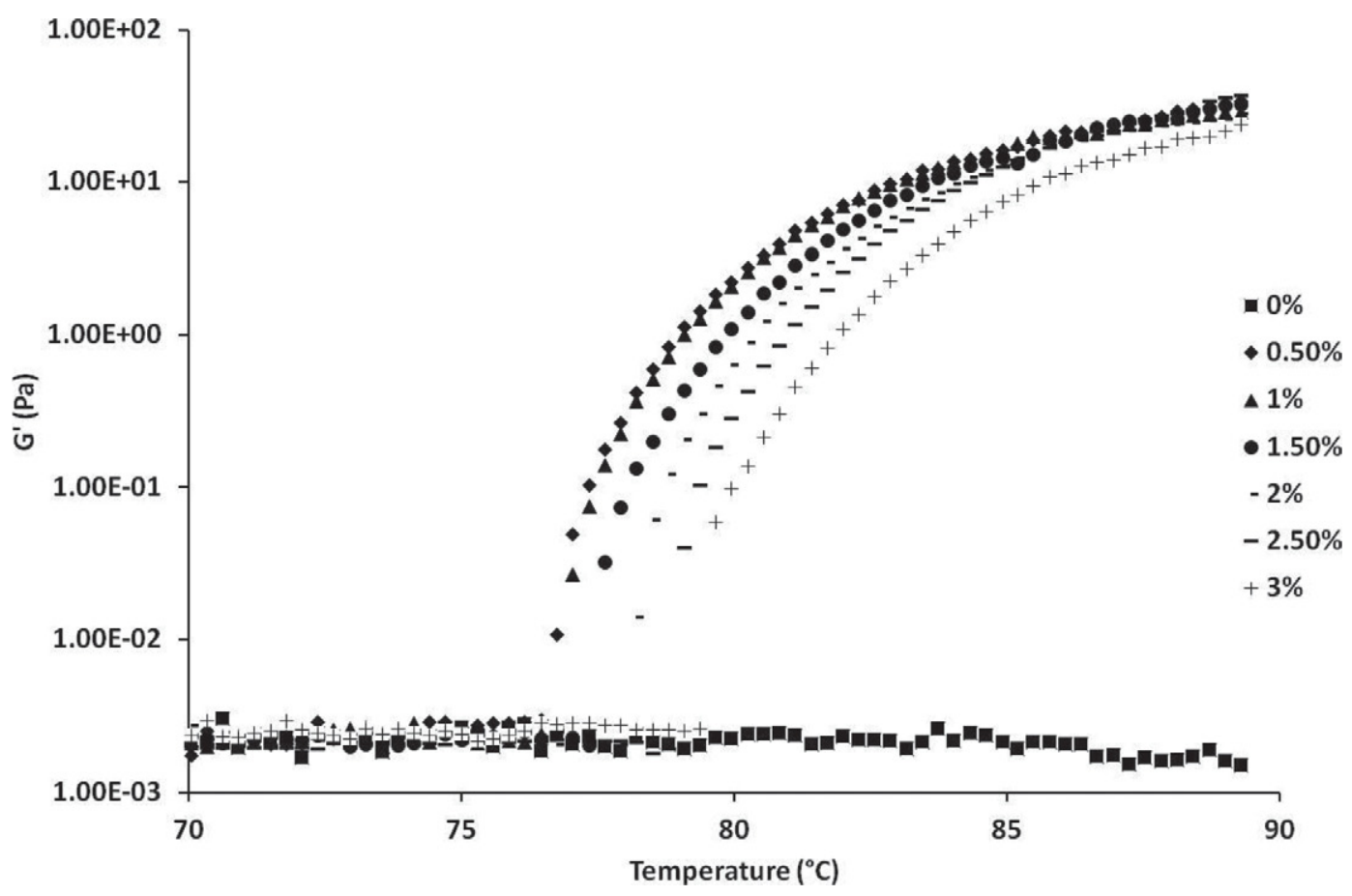

Figure 2. Determination of rheological behavior (storage modulus, $\mathrm{G}^{\prime}$ : elastic component) of whey protein dispersions in variable NaCl environments (from 0 to $3 \%$ ) from 30 to $90^{\circ} \mathrm{C}$. Each curve is representative of 3 independent experiments. 


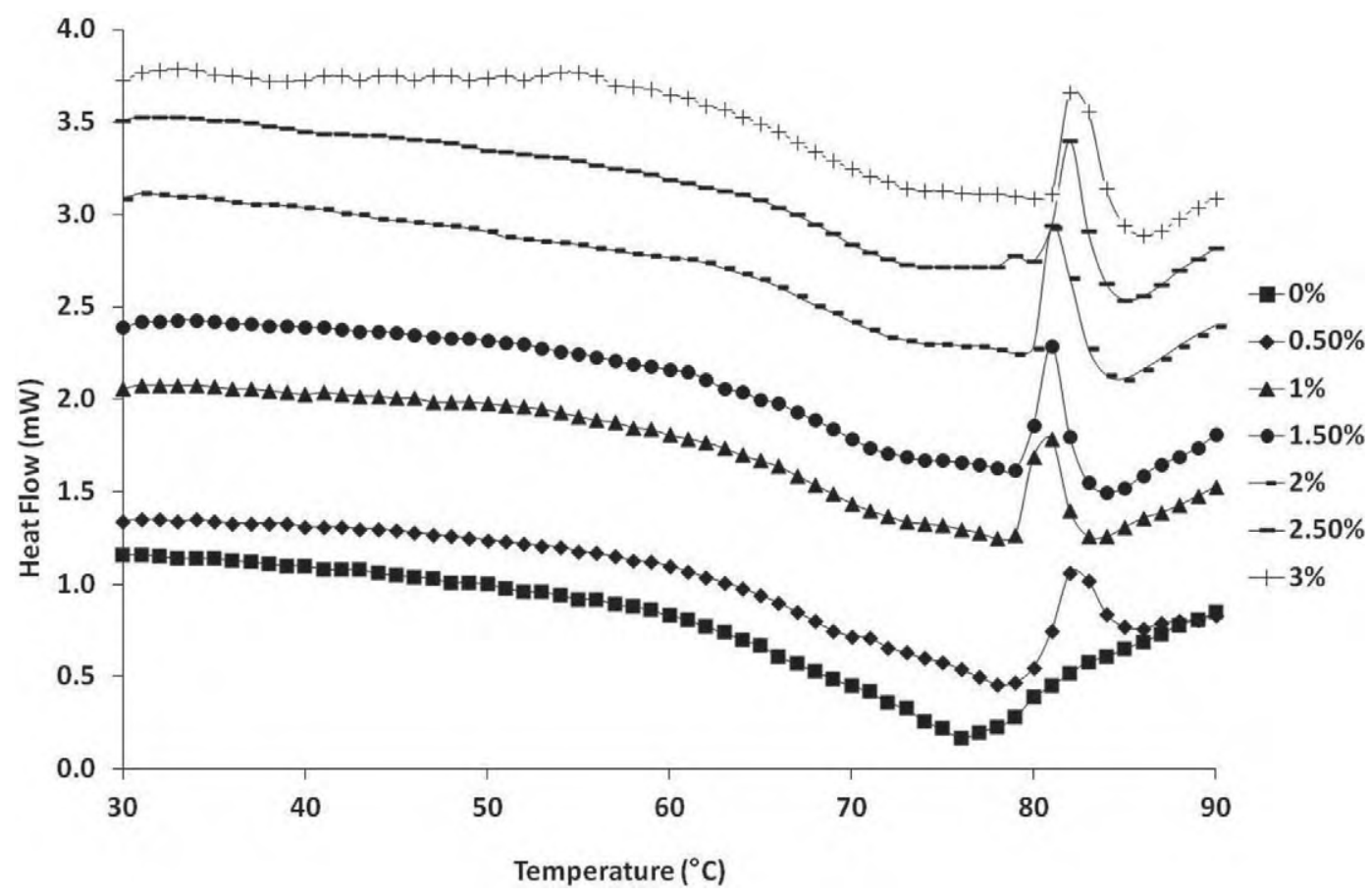

Figure 3. Thermograms of whey protein dispersions in variable $\mathrm{NaCl}$ environments (from 0 to $3 \%$ ). Each curve is representative of 3 independent experiments.

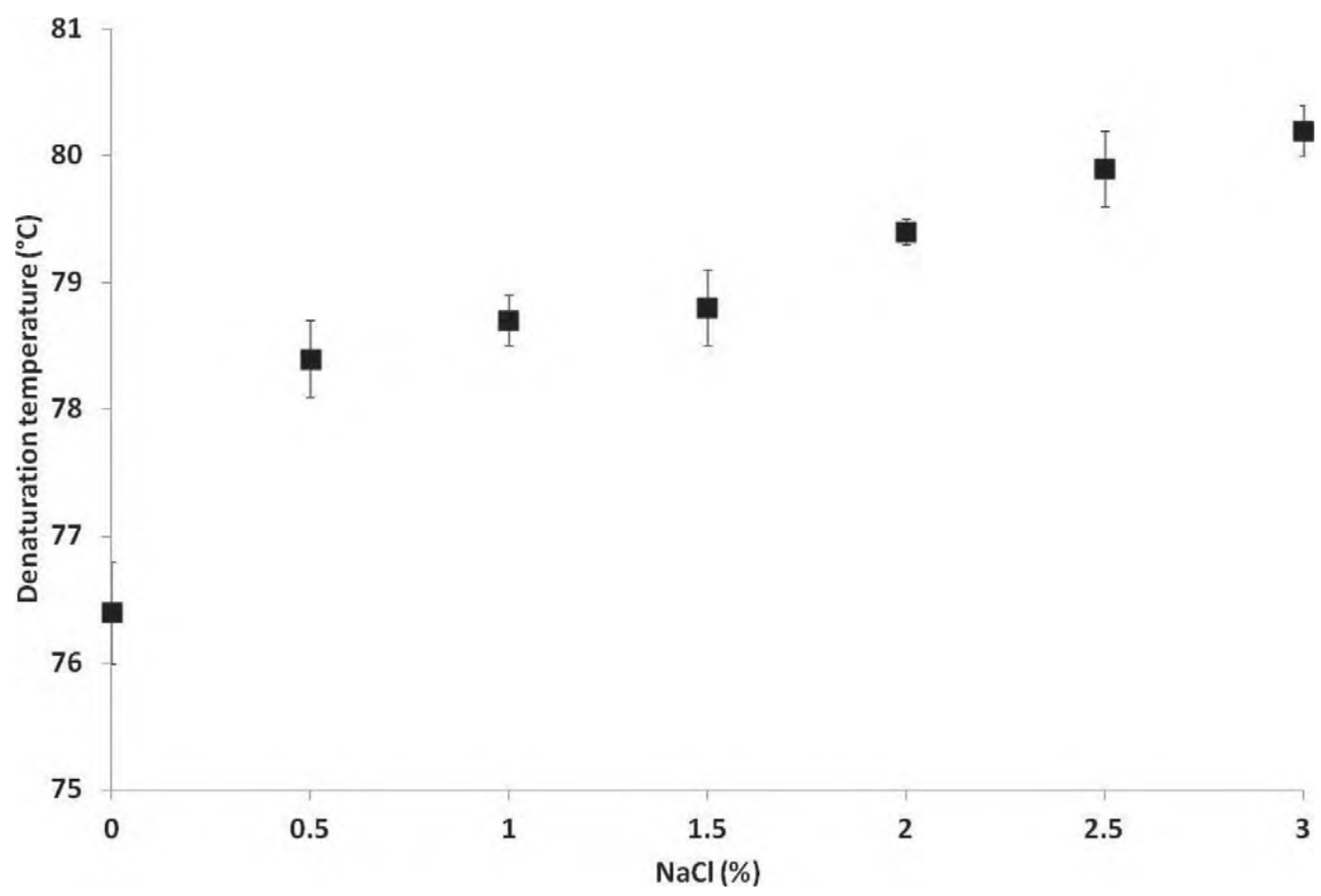

Figure 4. Denaturation temperature calculated from thermograms for whey protein isolate (WPI) dispersions in different NaCl environments. Results are the mean \pm SD of 3 independent analyses. 


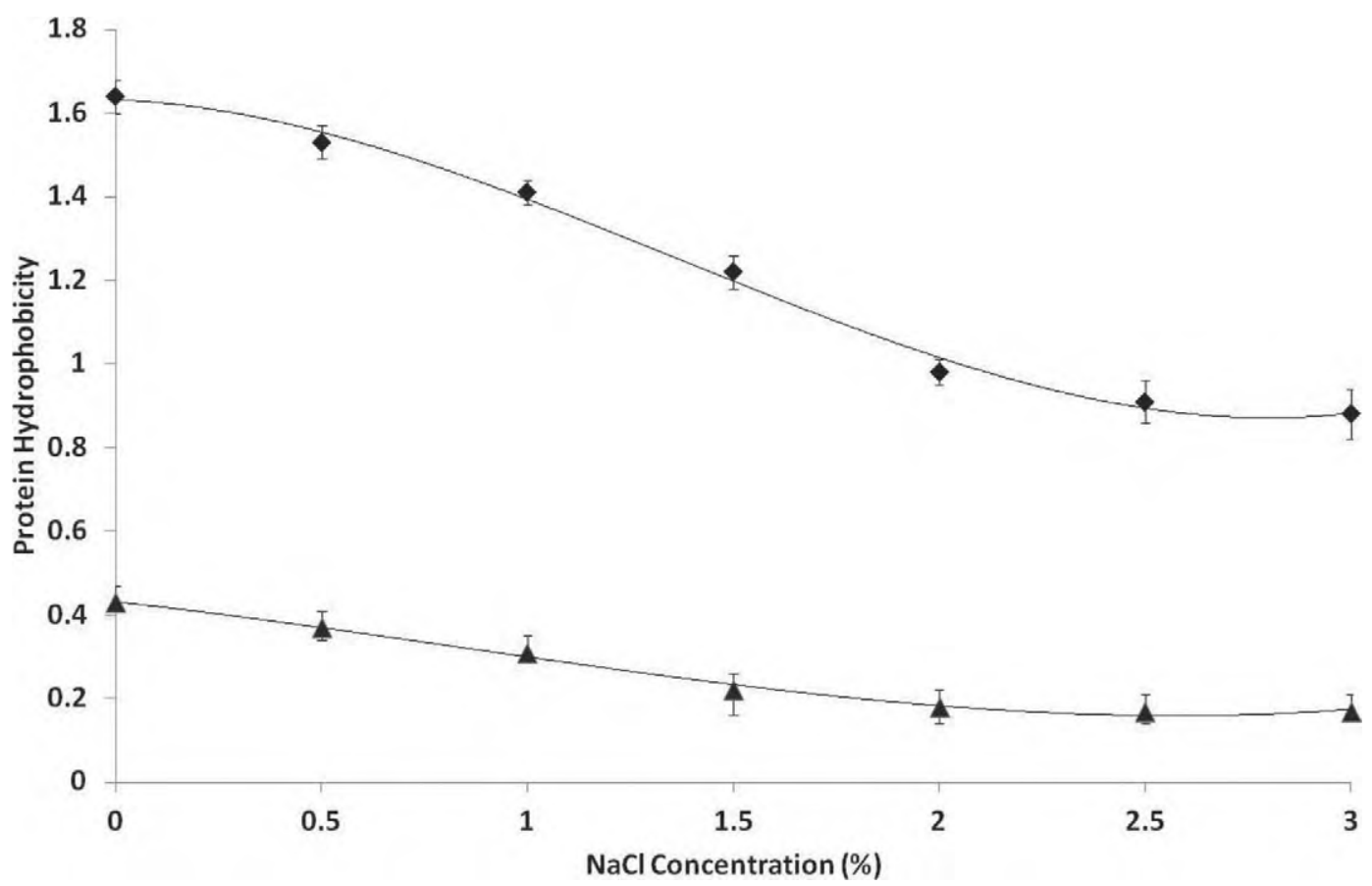

Figure 5. Protein surface hydrophobicity (PSH) as a function of $\mathrm{NaCl}$ concentration for whey protein isolate (WPI) dispersions at 30 ( $\mathbf{\Lambda}$ ) and $90^{\circ} \mathrm{C}(\bullet)$. Results are the mean \pm SD of 3 independent analyses.

2009). The dependence of PSH on variable $\mathrm{NaCl}$ concentrations for heated and unheated samples is reported in Figure 5. When increasing the $\mathrm{NaCl}$ concentration or heat treatment, or both, the results are indicative of a decreasing trend for PSH values. The maximum values of PSH were observed around 1.6 and $0.40(0 \%$ $\mathrm{NaCl}$ ), whereas the lowest were found around 0.8 and $0.17(3 \% \mathrm{NaCl})$ for unheated and heated dispersions, respectively.

\section{Secondary Structure of WPI Dispersions}

Curve Fitting and Peak Assignments. Secondderivative spectra were calculated from amide I and amide III bands. The frequencies of the bands obtained were used to define peak positions during the curvefitting procedure. During the iteration process, the peak positions were allowed to shift. The positions were only slightly changed (less than $1.5 \mathrm{~cm}^{-1}$ ). Optimal fits were obtained when the root mean square was in the range of $10^{-4}$. Figures $6 \mathrm{~A}$ and $\mathrm{B}$ present an example of the amide I and amide III regions fitted with a Gaussian line shape function for WPI in water at $30^{\circ} \mathrm{C}$. Peak assignments of the amide I region were made using the results of former studies collected for globular proteins (Byler and Susi, 1986). The following structures were assigned: 1,700 to $1,660 \mathrm{~cm}^{-1}$, turns; 1,652 to 1,648 $\mathrm{cm}^{-1}$, $\alpha$-helix; 1,648 to $1,642 \mathrm{~cm}^{-1}$, unordered; and 1,640 to $1,620 \mathrm{~cm}^{-1}, \beta$-sheet. The same procedure was followed for the amide III region. Tentative assignments of amide III were also already done following Cai and Singh (1999): 1,330 to $1,295 \mathrm{~cm}^{-1}$, $\alpha$-helix; 1,295 to $1,270 \mathrm{~cm}^{-1}, \beta$-turns; 1,270 to $1,250 \mathrm{~cm}^{-1}$, unordered; and 1,250 to $1,220 \mathrm{~cm}^{-1}, \beta$-sheet.

The amide I band was deconvoluted in 8 peaks (Figure 6A). The $\beta$-sheet structures were related to 3 bands. The band at $1,634 \mathrm{~cm}^{-1}$ is known to be strongly characteristic of amide groups involved in the extended $\beta$-sheet structure (Byler and Susi, 1986), whereas bands at 1,616 and $1,626 \mathrm{~cm}^{-1}$ exhibited low-frequency $\beta$-sheets. The low-frequency band at $1,616 \mathrm{~cm}^{-1}$ may have been caused by aromatic side chains $(\mathrm{C}=\mathrm{C}$ stretching vibrations) of the individual amino acids (Susi and Byler, 1988) and did not contribute much to the secondary structure. The relative intensity of the band at $1,634 \mathrm{~cm}^{-1}$ was the strongest, even though $\alpha$-helix/random coils and turns were detectable. The band at $1,626 \mathrm{~cm}^{-1}$ was also assigned to $\beta$-sheet structure and, as evidenced by its low wave number position, was assigned to the formation of intermolecular $\beta$-sheet structure. The unordered structures were assigned to 2 bands $\left(1,641\right.$ and $\left.1,647 \mathrm{~cm}^{-1}\right)$ and $\alpha$-helix structures to the $1,655 \mathrm{~cm}^{-1}$ band. Finally, the presence of 1,666 and 1,681 bands were related to $\beta$-turn structures. The 

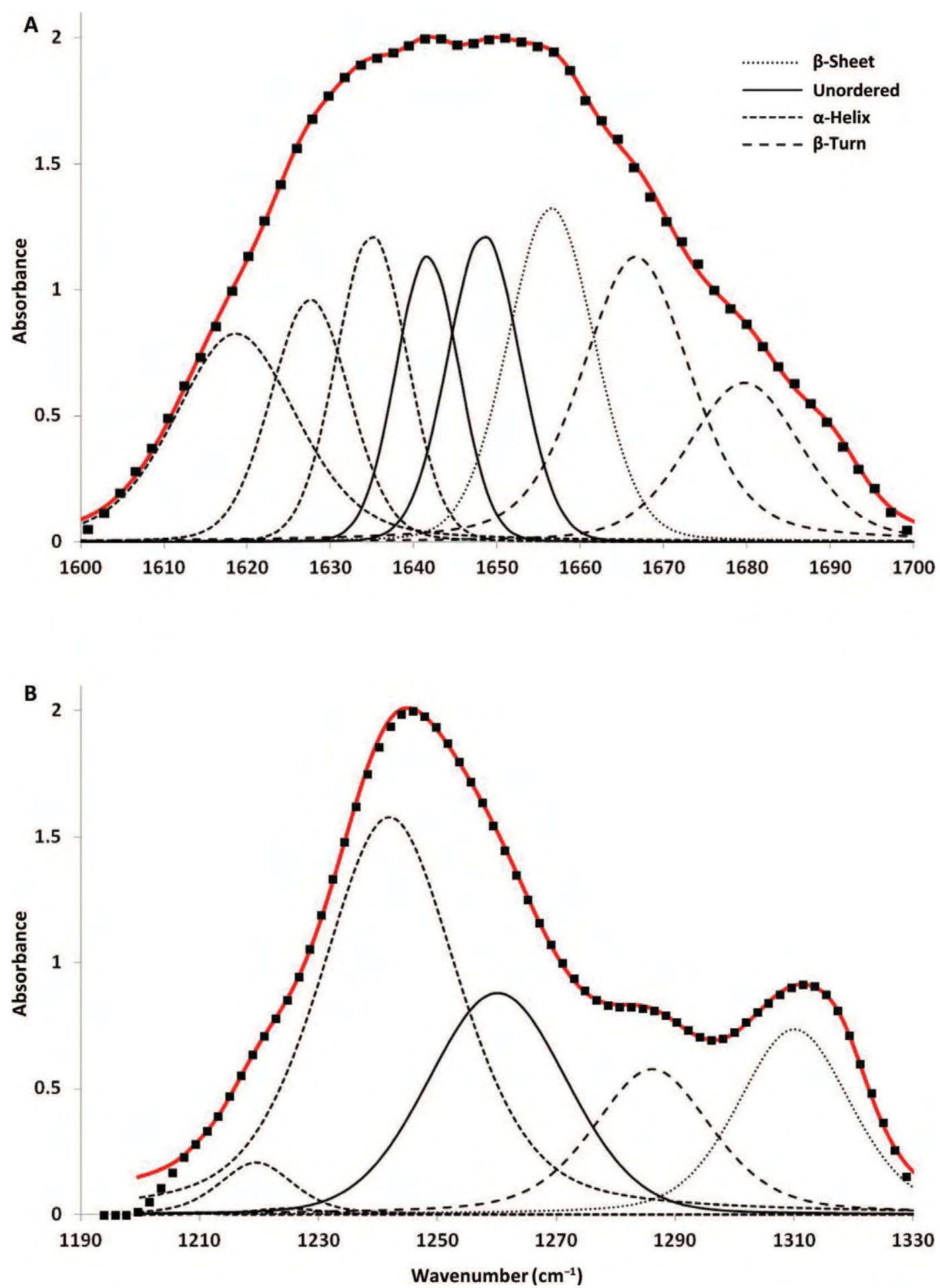

Figure 6. Example of Fourier transform infrared (FTIR) spectra obtained for whey protein dispersions in water at $90^{\circ} \mathrm{C}$. Amide I $(\mathrm{A})$ and amide III (B) region were fitted at peak positions obtained from second-derivative spectra followed by Gaussian curve fitting. Solid black squares represent experimental data; red (thick black in grayscale) curves represent the sum of the individual Gaussian components ( $\beta$-sheets, unordered structures, $\alpha$-helixes, and $\beta$-turns). Color version available in the online PDF. 
Table 2. Structural component ( $\beta$-sheet, unordered, $\alpha$-helix, and $\beta$-turn) percentage areas obtained for native whey protein dispersions in different $\mathrm{NaCl}$ environments measured from amide I and amide III at 30 and $90^{\circ} \mathrm{C}$ (mean of 3 independent analyses)

\begin{tabular}{|c|c|c|c|c|c|c|c|c|c|c|c|c|}
\hline \multirow{2}{*}{$\begin{array}{l}\text { Structural } \\
\text { component } \\
(\%)\end{array}$} & \multicolumn{6}{|c|}{ At $30^{\circ} \mathrm{C}$} & \multicolumn{6}{|c|}{ At $90^{\circ} \mathrm{C}$} \\
\hline & \multicolumn{6}{|c|}{$\mathrm{NaCl}$ concentration $(\%)$} & \multicolumn{6}{|c|}{$\mathrm{NaCl}$ concentration (\%) } \\
\hline \multicolumn{13}{|l|}{ Amide I } \\
\hline$\beta$-sheet & 40.4 & $41.6^{\mathrm{NS}}$ & $38.9^{*}$ & $41.6^{\mathrm{NS}}$ & $41.6^{\mathrm{NS}}$ & $42.6^{\mathrm{NS}}$ & 62.3 & $59.7^{\mathrm{NS}}$ & $47.3^{*}$ & $44.7^{* *}$ & $47.6^{*}$ & $47.6^{*}$ \\
\hline Unordered & 21.6 & $21.5^{\mathrm{NS}}$ & $23.5^{\mathrm{NS}}$ & 24.1 & $24.3^{\mathrm{NS}}$ & $22.4^{\mathrm{NS}}$ & 10.6 & $8.0^{\mathrm{NS}}$ & $13.4^{*}$ & $14.0^{*}$ & $15.2^{* *}$ & $14.8^{* *}$ \\
\hline \multicolumn{13}{|l|}{ Amide III } \\
\hline$\beta$-sheet & 44.9 & $46.3^{\mathrm{NS}}$ & $45.3^{\mathrm{NS}}$ & $43.2^{\mathrm{NS}}$ & $45.8^{\mathrm{NS}}$ & $48.4^{*}$ & 71.1 & $58.7^{* *}$ & $61.0^{*}$ & $65.1^{*}$ & $55.7^{* *}$ & $53.0^{* * *}$ \\
\hline Unordered & 22.5 & $20.0^{\mathrm{NS}}$ & $17.2^{*}$ & $22.4^{\mathrm{NS}}$ & $21.4^{\mathrm{NS}}$ & $18.4^{*}$ & 10.3 & $13.2^{*}$ & $13.9^{*}$ & $12.7^{*}$ & $17.4^{* * *}$ & $18.0^{* * *}$ \\
\hline$\beta$-turn & 14.7 & $18.0^{*}$ & $19.7^{*}$ & $16.6^{\mathrm{NS}}$ & $16.4^{\mathrm{NS}}$ & $16.3^{\mathrm{NS}}$ & 5.3 & $17.5^{* *}$ & $17.3^{* *}$ & $12.3^{*}$ & $18.0 * *$ & $17.8^{* *}$ \\
\hline$\alpha$-helix & 17.8 & $15.7^{*}$ & $17.8^{\mathrm{NS}}$ & $17.7^{\mathrm{NS}}$ & $16.3^{\mathrm{NS}}$ & $16.9^{\mathrm{NS}}$ & 13.3 & $10.7^{\mathrm{NS}}$ & $7.8^{*}$ & $9.8^{\mathrm{NS}}$ & $8.9^{\mathrm{NS}}$ & $11.2^{\mathrm{NS}}$ \\
\hline
\end{tabular}

*** $P<0.001 ;{ }^{* *} P<0.01 ; * P<0.05 ;{ }^{\mathrm{NS}} P>0.05$.

amide III band was deconvoluted in 5 peaks (Figure $6 \mathrm{~B})$. The maximum absorbance for $\beta$-sheets ( 2 bands) and $\alpha$-helix (1 band) was around $1,241 \mathrm{~cm}^{-1}$ and 1,318 $\mathrm{cm}^{-1}$, respectively. The wavenumbers at 1,261 and $1,284 \mathrm{~cm}^{-1}$ showed unordered and $\beta$-turn structures.

Quantitative Analysis. Areas calculated from the fitted spectra were considered to be proportional to the conformational elements that were assigned and are presented in Table 2. From amide I and III, no significant differences in structural percentages were noticed during $\mathrm{NaCl}$ increase for WPI dispersions without heating. Nevertheless, differences were observed between amide I and III results upon heating for the same salt concentration. For example, in water, the distribution in $\alpha$-helix, $\beta$-sheet, $\beta$-turn, and unordered structures obtained was around $22,40,16$, and $22 \%$ at $30^{\circ} \mathrm{C}$ and $20,62,7$, and $11 \%$ at $90^{\circ} \mathrm{C}$ for amide I. For amide III, the percentages obtained were $18,45,15$, and $23 \%$ and $13,71,5$, and $10 \%$ for 30 and $90^{\circ} \mathrm{C}$, respectively (Table 2). Nevertheless, these results were consistent with those found in the literature for globular proteins (Panick et al., 1999).

\section{DISCUSSION}

\section{WPI Dispersions Size and Morphology with Combined Effect of $\mathrm{NaCl}$ and Heat}

Dispersions in Water. Concomitant observations were obtained from TEM images and size analyses. Well-separated roughly spherical nanoparticles (around $70 \mathrm{~nm}$ ) were observed by TEM and measured by DLS. Another population was also found by DLS with a $D_{h}$ around $6 \mathrm{~nm}$. These small particles were not visible on TEM images certainly due to the magnification used and may correspond to individual whey proteins. These
$2 \mathrm{D}_{\mathrm{h}}$ are in agreement with values determined by Martinez et al. (2009) and Schmitt et al. (2007) for $\beta$-LA alone (corresponding to the first peak) and serum heatinduced milk proteins (corresponding to the second peak). The lack of aggregation can be related to the presence of substantial negative charge. Hence, strong electrostatic repulsions between molecules may prevent them from coming into close proximity (Baussay et al., 2004). For heated dispersions in water, the $D_{h}$ value obtained by DLS was in agreement with values reported by others (Schmitt et al., 2011). This also coincides well with the particle size determination made from TEM images and assuming a complete protein denaturation and formation of clumps of big soluble spherical aggregates.

Dispersions in Low- $\mathrm{NaCl}$ Environments $(<200 \mathrm{mmol} / \mathrm{kg})$. The addition of sodium chloride in the system affected the size and morphology of the WPI aggregates. Low salt concentrations (86 mmol/ $\mathrm{kg}$ ) resulted in the formation of small clumpy aggregates (TEM images). Nevertheless, the $\mathrm{D}_{\mathrm{h}}$ were not significantly different from those found in water. These discordances may be correlated to the important standard deviation found for the $\mathrm{D}_{\mathrm{h}}$. Aggregation is known to be strongly influenced by attractive and repulsive forces. The major forces favoring protein aggregation are hydrophobic and van der Waals forces, whereas electrostatic and hydration repulsions oppose this phenomenon. It seems that WPI started to aggregate above a critical salt concentration. Similarly, (Unterhaslberger et al., 2006) had already shown that when low amounts of $\mathrm{NaCl}$ were added $(<60 \mathrm{mmol} / \mathrm{kg})$, an insufficient number of chloride ions may have screened the positive charge of protein so that the preferential hydration forces were prevalent. In our concentrations, the electrostatic repulsion between protein molecules 
may have been screened sufficiently and more chloride ions could bind to the protein surface so that the preferential hydration by water was overcome, leading to aggregation. It appeared also that at low ionic strength the primary aggregates associated mainly head to tail (Pouzot et al., 2005). This enabled the protein molecules to approach closely enough together to form clumpy aggregates. Conversely, the $\mathrm{D}_{\mathrm{h}}$ and particle diameters observed by DLS/TEM of the heat-treated samples with or without salt presented a monomodal distribution showing a decreasing trend and totally differed from the particle size distribution of non-heat-treated dispersions. This phenomenon is a characteristic of an ongoing protein denaturation (Schokker et al., 1999). These findings can be explained by the second effect of ionic strength (i.e., salting-out effect of salts). At $\mathrm{NaCl}$ concentrations $(\leq 200 \mathrm{mmol} / \mathrm{kg})$, more chloride ions bind to the protein surface so that preferential hydration by water is overcome, leading to the observed denaturation and further protein aggregation coagulation phenomenon. Some other findings (Unterhaslberger et al., 2006; Nicorescu et al., 2008) also support our results, although it seems that it widely depends on co-solute, concentration, chemical environment, as well as the technological and operating conditions.

Dispersions in High- $\mathrm{NaCl}$ Environments (>200 mmol/ $\mathrm{kg}$ ). Increasing $\mathrm{NaCl}$ up to $258 \mathrm{mmol} /$ $\mathrm{kg}$ resulted in an acceleration of WPI aggregation and the formation of denser aggregates. Dynamic light scattering and SLS measurements were in agreement with TEM images and the presence of aggregates were detected. From 258 to $517 \mathrm{mmol} / \mathrm{kg}$, the electrostatic repulsions between protein molecules were screened more efficiently (i.e., the ionic strength was high enough to screen electrostatic interactions). These networks consisted of aggregated protein particles that are typically between 0.1 and $10 \mu \mathrm{m}$ in diameter, hence forming a large number of aggregated protein particles within each particle, associated into particulate structures that have relatively large sizes (Langton and Hermansson, 1996; Verheul et al., 1998). It is worth noting that the contrast between particles and background in the TEM images was higher at these concentrations, depicting a denser structure of WPI aggregates. Such local densification and branching association of the protein aggregates in salt aqueous environment was reported by others for whey proteins (Pouzot et al., 2004). Upon heating the dispersions in higher salt concentrations (258-517 mmol $/ \mathrm{kg})$, particle sizes measured by DLS and TEM were well correlated and showed a similar decreasing trend. As already discussed, the likely explanation for smaller particles could be a combined salt/ heat-induced denaturation process, leading into solid aggregated gels at higher salt concentrations. Moreover, the size and microstructure of particles was insensitive to higher salt concentration $(>200 \mathrm{mmol} / \mathrm{kg})$. The transition from spherical/compact protein aggregates to linear ones upon salt/heat increase has already been reported for WPI dispersions (1\% wt) at $85^{\circ} \mathrm{C}$ (Schmitt et al., 2007).

\section{Rheological and Thermal Properties of WPI Dispersions}

Gelling properties of WPI dispersions are significantly influenced by the concentration of $\mathrm{NaCl}$ present in solution (Mulvihill and Ennis, 2003). The lack of gelation in the absence of salt occurs because protein molecules have substantial negative charges; hence, a relatively strong electrostatic repulsion occurs between unfolded protein molecules, which prevents them from coming into close proximity (Bryant and McClements, 1998). It is virtually impossible to induce gelation by denatured proteins, in itself, as individual molecules must associate with one another to form a continuous network (Mulvihill et al., 1990). In the presence of $\mathrm{NaCl}$, the $\mathrm{G}^{\prime}$ increase is logical, as salt addition leads to a reduced intermolecular repulsion of unfolded protein molecules. Thus, it results in an increase in both the protein-protein interactions and their aggregation capacity, which finally contributes to a strong 3-dimensional protein network that contributes to a gel (Lorenzen and Schrader, 2006). It is noteworthy that higher $\mathrm{G}^{\prime}$ values and maximum gel strength were observed at low $\mathrm{NaCl}$ concentrations. These results can be explained by the screening of negative charges carried by unfolded proteins, which in turn allowed an increase in strong protein-protein interactions in this salt range. A considerable increase in the gel firmness and stabilizing effect in the presence of $0.2 \mathrm{M} \mathrm{NaCl}$ was confirmed by others (Bertrand and Turgeon, 2007). Nevertheless, the addition of higher concentrations of $\mathrm{NaCl}(>200 \mathrm{mmol} /$ $\mathrm{kg}$ ) has shown negative influence on gel formation/ firmness by decreasing protein unfolding (Boye et al., 1995) and increasing protein-solvent interactions (Sun and Arntfield, 2011). At higher $\mathrm{NaCl}$ ranges (>200 $\mathrm{mmol} / \mathrm{kg}$ ), Chantrapornchai and McClements (2002) observed a decrease in $\mathrm{G}^{\prime}$ due to either an increase in size of insoluble heat-induced aggregates or a decrease in the number of protein-protein contacts.

By increasing the ionic strength, a significant increase in denaturation temperature for WPI dispersions was observed. Such a shift in denaturation temperature was due to structural rearrangements induced by $\mathrm{NaCl}$. An identical increase in thermal stability has also been observed for whey proteins (Nicorescu et al., 2008) and 
$\beta$ - LG (Haug et al., 2009). Whey protein isolate dispersions are composed of 2 major proteins $(\beta-L G$ and $\alpha$-LA) presenting denaturation temperatures around 76 and $67^{\circ} \mathrm{C}$, respectively (Ju et al., 1999). These temperatures are normally $\mathrm{pH}$ dependent. For example, the temperature of denaturation increased $\left(85^{\circ} \mathrm{C}\right)$ for $\beta$-LG (Boye et al., 1997) and decreased $\left(58^{\circ} \mathrm{C}\right.$ ) for $\alpha$-LA (Bernal and Jelen, 1984) by lowering their $\mathrm{pH}$. In our case, the $\mathrm{pH}$ of all systems remained stable. The shifts observed in denaturation ( $\mu$ DSC) and gelling (rheometer) temperatures for WPI dispersions are well corroborated and showed that an effect of combined heat treatment and ionic strength may become a rate-limiting factor for their final functional properties.

\section{PSH Index}

The significant decrease in the PSH index with $\mathrm{NaCl}$ addition could be related to a lower availability of hydrophobic groups, certainly due to the formation of large aggregates. This evolution was characteristic of the presence of fewer hydrophobic sites available to ANS markers. This may be related to the fact that hydrophobic groups are buried inside the native structure of WPI molecules, so that with the salt-induced aggregation it is possible that their access to ANS probes is limited (Moro et al., 2001). Another explanation may be an interaction between hydrophobic sites of the proteins during salt-induced aggregation and a reduction in the number of available ANS-binding sites (Schmitt et al., 2007). Similarly, the PSH decrease observed for heated WPI dispersions may be due to an ongoing denaturation-aggregation phenomenon and structural collapse due to high temperature, resulting in limited availability of ANS-binding sites and, in turn, insoluble aggregates with decreased surface hydrophobicity. Some authors also observed a decrease in the PSH of whey proteins when increasing the temperature from 75 to $80^{\circ} \mathrm{C}$ (Carbonaro et al., 1996). It is worth noting that although a gradual decrease in PSH values occurred upon addition of $\mathrm{NaCl}$ under heated and unheated conditions, except with $1.5 \% \mathrm{NaCl}$, this decrement was limited and coincided well with TEM micrographs and summarized data.

\section{Secondary Structure of WPI with Salt/Heat Augmentation}

Up to now, the amide I spectral region was the most commonly used band because of its very strong signal but some recent results indicate that the amide III region gives a better prediction for protein secondary structures than does amide I (Cai and Singh, 2004;
Hussain et al., 2011a). This is because the amide I band suffers from an unstructured spectral contour and an overlap of the random coil and $\alpha$-helix bands (Cai and Singh, 2004). In this work, the distributions of components within classes of structures are reproducible and the tendencies are exactly the same whatever the band analyzed. At room temperature (and $\mathrm{pH}$ around 6.6), the conformation ( $\beta$-sheet, unordered, $\beta$-turn, and $\alpha$-helix) of whey proteins was not appreciably altered by $\mathrm{NaCl}$ (from 86 to $517 \mathrm{mmol} / \mathrm{kg}$ ). These results are corroborated by Boye et al. (1996). A similar effect of $\mathrm{NaCl}$ on $\beta$-LG secondary structure has been reported by others (Verheul et al., 1998; Kavanagh et al., 2000). Upon heat treatment without salt, $\beta$-sheet structures increased primarily at the cost of $\beta$-turn and unordered structures. This ongoing denaturation/aggregation process at elevated temperatures was also observed during rheological behavior study of WPI dispersion, as discussed earlier. These results are in agreement with those of Panick et al. (1999) for $\beta-L G$ studied by spectroscopic and scattering techniques. Conversely, these results differs from those of Zhu and Damodaran (1994) who described a progressive decrease in $\beta$-sheets along an increase in unordered structures while studying heat-induced conformational changes in WPI with different heating times. This conflict may be attributed to the method adopted for heating proteins. Moreover, a salt increase ( 86 to $517 \mathrm{mmol} / \mathrm{kg}$ ) tended to illustrate a stabilizing effect of $\mathrm{NaCl}$ (Boye et al., 1996; Verheul et al., 1998), suggesting an increase in thermal stability of WPI dispersions followed by a decrease in percentages of secondary structural elements. This increase in thermal stability was also observed by DSC analysis, showing that higher temperatures may be required to disrupt the native proteins structure at higher ionic strength.

\section{CONCLUSIONS}

This work demonstrated that gelation properties of whey protein depend on both salt level and how heat treatment is applied. Experimental data showed that during heat treatment and at low ionic strength, the gel elastic modulus increased and the strongest gel stiffness was achieved. Higher salt concentrations led to a weaker gel, whereas no gels at all were formed without salt. Additionally, $\mathrm{NaCl}$ addition along with dynamic heat treatment showed a stabilizing effect on the secondary structural elements of both amide I and III bands and higher denaturation temperatures. A morphological investigation showed a transition from spherical/compact protein aggregates to linear ones due to combined salt/ heat effect. Moreover, by combining the results of DLS 
and TEM with those of PSH, one may conclude that the number of hydrophobic sites available decreased significantly because of the formation of denser aggregates. For the first time, a combination of techniques with additional work on fundamental aspects of whey proteins was presented. These results add additional value and could validate other studies that independently made such observations. Careful adjustment of heat and $\mathrm{NaCl}$ concentration are necessary to effectively use WPI as a functional additive. Nevertheless, further work is required to understand sequential events occurring during salt- and temperature-induced unfolding and the aggregation process of whey proteins. This will be done in a future paper by use of FTIR combined with 2-dimensional correlation spectroscopy.

\section{ACKNOWLEDGMENTS}

The authors are gratefully indebted to the Pakistan Ministry of Higher Education Commission (HEC, Islamabad, Pakistan) for financial support.

\section{REFERENCES}

Baussay, K., C. Le Bon, T. Nicolai, D. Durand, and J.-P. Busnel. 2004. Influence of the ionic strength on the heat-induced aggregation of the globular protein $\beta$-lactoglobulin at $\mathrm{pH}$ 7. Int. J. Biol. Macromol. 34:21-28.

Bernal, V., and P. Jelen. 1984. Effect of calcium binding on thermal denaturation of bovine $\alpha$-lactalbumin. J. Dairy Sci. 67:2452-2454.

Bertrand, M.-E., and S. L. Turgeon. 2007. Improved gelling properties of whey protein isolate by addition of xanthan gum. Food Hydrocoll. 21:159-166.

Boye, J. I., I. Alli, A. A. Ismail, B. F. Gibbs, and Y. Konishi. 1995. Factors affecting molecular characteristics of whey protein gelation. Int. Dairy J. 5:337-353.

Boye, J. I., A. A. Ismail, and I. Alli. 1996. Effects of physicochemical factors on the secondary structure of $\beta$-lactoglobulin. J. Dairy Res. 63:97-109.

Boye, J. I., C. Y. Ma, A. Ismail, V. R. Harwalkar, and M. Kalab. 1997. Molecular and microstructural studies of thermal denaturation and gelation of $\beta$-lactoglobulins A and B. J. Agric. Food Chem. 45:1608-1618.

Bryant, C. M., and J. D. McClements. 1998. Molecular basis of protein functionality with special consideration of cold-set gels derived from heat-denatured whey. Trends Food Sci. Technol. 9:143-151.

Byler, D. M., and H. Susi. 1986. Examination of the secondary structure of proteins by deconvolved FTIR spectra. Biopolymers 25:469-487.

Cai, S., and B. R. Singh. 1999. Identification of $\beta$-turn and random coil amide III infrared bands for secondary structure estimation of proteins. Biophys. Chem. 80:7-20.

Cai, S., and B. R. Singh. 2004. A distinct utility of the amide III infrared band for secondary structure estimation of aqueous protein solutions using partial least squares methods. Biochemistry 43:2541-2549.

Carbonaro, M., F. Bonomi, S. Iametti, and E. Carnovale. 1996. Modifications in disulfide reactivity of milk induced by different pasteurization conditions. J. Food Sci. 61:495-500.

Chantrapornchai, W., and D. J. McClements. 2002. Influence of $\mathrm{NaCl}$ on optical properties, large-strain rheology and water holding capacity of heat-induced whey protein isolate gels. Food Hydrocoll. 16:467-476.
Gaiani, C., P. Schuck, J. Scher, S. Desobry, and S. Banon. 2007. Dairy powder rehydration: Influence of protein state, incorporation mode, and agglomeration. J. Dairy Sci. 90:570-581.

Haug, I. J., H. M. Skar, G. E. Vegarud, T. Langsrud, and K. I. Draget. 2009. Electrostatic effects on beta-lactoglobulin transitions during heat denaturation as studied by differential scanning calorimetry. Food Hydrocoll. 23:2287-2293.

Hussain, R., C. Gaiani, L. Aberkane, J. Ghanbaja, and J. Scher. 2011a. Multiscale characterization of casein micelles under $\mathrm{NaCl}$ range conditions. Food Biophys. 6:503-511.

Hussain, R., C. Gaiani, L. Aberkane, and J. Scher. 2011b. Characterization of high-milk-protein powders upon rehydration under various salt concentrations. J. Dairy Sci. 94:14-23.

Ikeda, S., E. A. Foegeding, and T. Hagiwara. 1999. Rheological study on fractal nature of protein gel structure. Langmuir 15:8584-8589.

Ju, Z. Y., N. Hettiarachchy, and A. Kilara. 1999. Thermal properties of whey protein aggregates. J. Dairy Sci. 82:1882-1889.

Kavanagh, G. M., A. H. Clark, and S. B. Ross-Murphy. 2000. Heatinduced gelation of globular proteins: Part 3. Molecular studies on low $\mathrm{pH} \beta$-lactoglobulin gels. Int. J. Biol. Macromol. 28:41-50.

Langton, M., and A. M. Hermansson. 1996. Image analysis of particulate whey protein gels. Food Hydrocoll. 10:179-191.

Lorenzen, P. C., and K. Schrader. 2006. A comparative study of the gelation properties of whey protein concentrate and whey protein isolate. Lait 86:259-271.

Madureira, A. R., T. Tavares, A. M. P. Gomes, M. E. Pintado, and F. X. Malcata. 2010. Invited review: Physiological properties of bioactive peptides obtained from whey proteins. J. Dairy Sci. 93:437-455.

Martinez, M. J., C. C. Sánchez, J. M. R. Patino, and A. M. R. Pilosof. 2009. Interactions in the aqueous phase and adsorption at the air-water interface of caseinoglycomacropeptide (GMP) and beta-lactoglobulin mixed systems. Colloids Surf. B Biointerfaces 68:39-47.

Michalski, M. C., R. Cariou, F. Michel, and C. Garnier. 2002. Native vs. damaged milk fat globules: Membrane properties affect the viscoelasticity of milk gels. J. Dairy Sci. 85:2451-2461.

Moro, A., C. Gatti, and N. Delorenzi. 2001. Hydrophobicity of whey protein concentrates measured by fluorescence quenching and its relation with surface functional properties. J. Agric. Food Chem. 49:4784-4789.

Mulvihill, D. M., and M. P. Ennis. 2003. Functional milk proteins: Production and utilization. 1175-1228 Pages $1175-1228$ in Advanced Dairy Chemistry: Volume 1: Part B. P. F. Fox and P. L. H. McSweeney, ed. Kluwer Academic, New York, NY.

Mulvihill, D. M., D. Rector, and J. E. Kinsella. 1990. Effect of structuring and destructuring anionic ions on the rheological properties of thermally induced $\beta$-lactoglobulin gels. Food Hydrocoll. $4: 267-276$.

Nicorescu, I., C. Loisel, C. Vial, A. Riaublanc, G. Djelveh, G. Cuvelier, and J. Legrand. 2008. Combined effect of dynamic heat treatment and ionic strength on denaturation and aggregation of whey proteins-Part I. Food Res. Int. 41:707-713.

Panick, G., R. Malessa, and R. Winter. 1999. Differences between the pressure- and temperature-induced denaturation and aggregation of $\beta$-lactoglobulin A, B, and AB monitored by FT-IR spectroscopy and small-angle X-ray scattering. Biochemistry 38:6512-6519.

Pouzot, M., D. Durand, and T. Nicolai. 2004. Influence of the ionic strength on the structure of heat-set globular protein gels at $\mathrm{pH} 7$. $\beta$-Lactoglobulin. Macromolecules 37:8703-8706.

Pouzot, M., T. Nicolai, R. W. Visschers, and M. Weijers. 2005. X-ray and light scattering study of the structure of large protein aggregates at neutral pH. Food Hydrocoll. 19:231-238.

Qi, P. X., and C. I. Onwulata. 2011. Physical properties, molecular structures, and protein quality of texturized whey protein isolate: Effect of extrusion moisture content. J. Dairy Sci. 94:2231-2244.

Schmitt, C., C. Bovay, M. Rouvet, S. Shojaei-Rami, and E. Kolodziejczyk. 2007. Whey protein soluble aggregates from heating with $\mathrm{NaCl}$ : Physicochemical, interfacial, and foaming properties. Langmuir 23:4155-4166. 
Schmitt, C., C. Bovay, A.-M. Vuilliomenet, M. Rouvet, and L. Bovetto. 2011. Influence of protein and mineral composition on the formation of whey protein heat-induced microgels. Food Hydrocoll. 25:558-567.

Schmitt, C., C. Bovay, A.-M. Vuilliomenet, M. Rouvet, L. Bovetto, R. Barbar, and C. Sanchez. 2009. Multiscale characterization of individualized $\beta$-lactoglobulin microgels formed upon heat treatment under narrow pH range conditions. Langmuir 25:7899-7909.

Schokker, E. P., H. Singh, D. N. Pinder, G. E. Norris, and L. K. Creamer. 1999. Characterization of intermediates formed during heat-induced aggregation of $\beta$-lactoglobulin $\mathrm{AB}$ at neutral $\mathrm{pH}$. Int. Dairy J. 9:791-800.

Sun, X. D., and S. D. Arntfield. 2011. Dynamic oscillatory rheological measurement and thermal properties of pea protein extracted by salt method: Effect of $\mathrm{pH}$ and $\mathrm{NaCl}$. J. Food Eng. 105:577-582.

Susi, H., and M. Byler. 1988. Fourier deconvolution of the amide I Raman band of proteins as related to conformation. Appl. Spectrosc. $42: 819-826$.

Unterhaslberger, G., C. Schmitt, C. Sanchez, C. Appolonia-Nouzille, and A. Raemy. 2006. Heat denaturation and aggregation of be- ta-lactoglobulin enriched WPI in the presence of arginine $\mathrm{HCl}$, $\mathrm{NaCl}$ and guanidinium $\mathrm{HCl}$ at $\mathrm{pH} 4.0$ and 7.0. Food Hydrocoll. 20:1006-1019.

Van Audenhaege, M., J. Belmejdoub, D. Dupont, A. Chalvin, S. Pezennec, Y. Le Gouar, F. Garnier-Lambrouin, M. Rabiller-Baudry, and G. Gesan-Guiziou. 2010. A methodology for monitoring globular milk protein changes induced by ultrafiltration: A dual structural and functional approach. J. Dairy Sci. 93:3910-3924.

Vardhanabhuti, B., and E. A. Foegeding. 2008. Effects of dextran sulfate, $\mathrm{NaCl}$, and initial protein concentration on thermal stability of $\beta$-lactoglobulin and $\alpha$-lactalbumin at neutral pH. Food Hydrocoll. 22:752-762.

Verheul, M., S. P. F. M. Roefs, and K. G. de Kruif. 1998. Kinetics of heat-induced aggregation of $\beta$-lactoglobulin. J. Agric. Food Chem. 46:896-903.

Zhu, H., and S. Damodaran. 1994. Heat-induced conformational changes in whey protein isolate and its relation to foaming properties. J. Agric. Food Chem. 42:846-855. 